\title{
Productive flight activity of bees in the active period in the conditions of Vinnytsia region
}

\author{
Olena Razanova $*$ iD | Vitaiy Kucheriavy ${ }^{(i D}$ | Lyudmyla Tsaruk ${ }^{2}$ | Halyna Lotka ${ }^{\text {iD }}$ | \\ Nadiya Novgorodska
}

aVinnytsia National Agrarian University, 21008, 3 Sunny str., Vinnytsia, Ukraine.

*Corresponding author: razanova_elena@rambler.ru

\begin{abstract}
The study aimed to identify the relationship between pollen collection, nectar, and seasonal dynamics of the brood of the bee colonies of the Ukrainian bee breed to study their active activity when changing the period of the active season. We compared the collection of nectar and pollen from honey plants of the garden, white acacia, and sunflower. The number of bees bringing pollen and nectar to the hive was recorded. The active work of bees to collect pollen is associated with the work of the uterus to lay eggs and the number of broods in the hives. Bee colonies increase their flight activity by collecting pollen in early spring and summer. By the beginning of the main honey harvest, pollination work is minimized, especially during the flowering of white acacia, and they switch to collecting nectar. Analysis of the results allows us to conclude that bees' daily dynamics that produce pollen increase in the spring to May and June.
\end{abstract}

Keywords bees, flight activity, fruit trees, sunflower, white acacia

\section{Introduction}

One of the promising industries is beekeeping. In addition to Ukraine being among the top ten world leaders in honey exports in sales, crop productivity also depends on bees. Beekeeping products, namely honey, wax, bee pollen, perga, royal jelly, bee venom, propolis, and others, are widely used in various economic sectors (Razanova 2018). The most important role of ecological beekeeping services for the planet's ecosystem is to preserve biological diversity due to the ability of bees to pollinate flowering plants (Skoromna and Razanova 2019).

Honey bees are the best among plant pollinators due to the ability of humans to control certain stages of the bee colony's life: control the volume of flying individuals and their activities, stimulate or limit their growth (Adamchuk 2020). The bee collects nectar, and during the flight from flower to flower, it transfers pollen for pollination. This process positively affects the viability of plants, increases their yields, and increases the number of plants on Earth (Hung et al 2018). When bees pollinate the flowers of crops, the yield increases by $30-60 \%$ and above, fruit tying and preservation of the ovary, the quality of fruits and seeds, their weight increases (Cherhyk et al 1972). Bees are the only factor that humans can control. The use of bee pollination in greenhouses makes it possible to obtain high yields of vegetables at the lowest cost and avoid laborious work on artificial pollination (Haeva 2015).

The diversity of wildlife is an indicator of the stability of ecosystems; therefore, conservation is one of the key tasks of modernity. Changes in the natural conditions and anthropogenic activity have caused a decrease in range and alterations in the functional organization of many plant species (Mudrak et al 2018; Mudrak et al 2019; Moskalets et al 2020; Pantsyreva et al 2020). The entry of various types of anthropogenic pollution into the atmosphere creates a high probability of entering toxic elements into beekeeping products during bees' active collection of nectar and pollen (Stroikov 1988).

The flight activity of bees in the colonies depends on the biological condition of the bee colonies, the presence of honey collection, the number of bribes and the duration and temperature of the environment, wind speed, and precipitation (Abrol 2006).

The optimum temperature for the flight of bees to collect food is from 17 to $32{ }^{\circ} \mathrm{C}$. Flight activity in bees of summer generation at an outdoor temperature of $32{ }^{\circ} \mathrm{C}$ is two times higher than at $21^{\circ} \mathrm{C}$. Bees that have emerged from hibernation show flight activity at pretty low temperatures but not below $8^{\circ} \mathrm{C}$. Bees' increased flight activity at $35^{\circ} \mathrm{C}$ and above is due to the additional need for water (Kryvtsov and Lebedev 2019).

Most species of honey plants of the Vinnytsia region begin to produce nectar at an air temperature of $14-15^{\circ} \mathrm{C}$, but there are also cherries, which secrete nectar at $10^{\circ} \mathrm{C}$. With increasing temperature from this limit, there is an increase in the nectar-producing activity of plants, which reaches its maximum in the range of $25-35^{\circ} \mathrm{C}$. Further increase in air temperature leads to a decrease in the amount of nectar released by plants.

The flight activity of bees at wind speeds up to $5-8 \mathrm{~m} / \mathrm{s}$ decreases to $40-45 \%, 12-15 \mathrm{~m} / \mathrm{s}$ - only $11-18 \%$ of bees fly out of the hive, above $24 \mathrm{~km} / \mathrm{h}$ - stops. The wind reduces the amount of nectar released by plants, especially in species with open nectaries (Losiev and Holovetskyi 2013). 
The optimum humidity for bees' flight at $20-25{ }^{\circ} \mathrm{C}$ is 20-60\%. Humidity affects the amount of nectar produced by plants and determines the concentration of sugars in it. As a rule, drought leads to an increase in the sugar content in nectar and reduces its amount (Moquet et al 2017).

Precipitation determines the nature of the nectar secretion of plants depending on their intensity. Short-term rains affect the intensity of nectar secretion and nectar quality, leading to the increased honey collection, especially at temperatures close to $28^{\circ} \mathrm{C}$. Prolonged rains cause a decrease in the concentration of sugars in the nectar, leading to bees leaving the plants they visited before rainfall.

The duration and range of bees also depend on many factors. The area of honey collection, from which bees intensively collect nectar, is within a radius of $2-2.5 \mathrm{~km}$. The age of bees does not affect the flight range (Kryvtsov and Lebedev 2019).

Depending on the level of honey collection and the distance from the source to the hive, the duration of bees' flight varies from 15 to 103 minutes. When collecting nectar, the flight duration is 10-60 minutes, and when collecting pollen - 6-30 minutes. During the day, the bee makes an average of 8-10 flights. One flight into the hive brings 30 $40 \mathrm{mg}$ of nectar or 10-15 mg of pollen.

The cost of feed for the flight activity of the average bee colonies during the season is $28-30 \mathrm{~kg}$, for the life and work of bees in the hive $-48-52 \mathrm{~kg}$ per year (Kryvtsov and Lebedev 2019).

The beginning of the active season in the central part of the Forest-Steppe falls in April when the air temperature reaches $12{ }^{\circ} \mathrm{C}$. The whole honey harvest season for the bee colonies is divided into five periods (Kryvtsov and Lebedev 2017; Kryvtsov and Lebedev 2019). The first - early spring-mid of May. Flight activity of bees at this time, as a rule, is low. Nectar productivity of vegetation is small, so a significant part of bees brings water and pollen to the nest. Families accumulate the largest amount of bee bread.

The second period is the last decade of May - the first two decades of June. In favorable weather, the stocks of honey in the nests noticeably increase. The duration of the flight day rises to 9 hours and, accordingly, the intensity of the flight. The third period is at the end of June-beginning of July. This time is characterized by a significant bringing of nectar by bees in the nests. The fourth period - the period of the main honey harvest and its onset depends on weather conditions in June. This period begins in the first decade of July and can last until the last decade of August. The duration of the flight day increases to 11 hours. The fifth period - autumn, which supports the nectar collection in the nest, comes very little. Pollen bribe can sometimes last until the last autumn flight the second half of October.

The type of honey harvest is determined by the set of species of honey plants, their number, and weather conditions during their flowering. According to the nature of the honey harvest, the forage conditions can be divided into two main types - those that: provide a supporting and main honey harvest. The main honey harvest is characterized by the flowering of the maximum number of honeybees with high nectar productivity and daily growths of the hive exceeding $2 \mathrm{~kg}$. During the maintenance period, the daily gain of the hive does not exceed $1 \mathrm{~kg}$.

The biological processes that underlie the growth and development of bee colonies and their food collection have always attracted scientists and practitioners' attention. Flight activity is an indirect indicator of the building activity of bees because their release of wax proportionally depends on the amount of food entering the nest. Therefore, the purpose of the research was to study the flight activity of bees in different periods of honey collection.

\section{Materials and Methods}

The research was carried out in the apiary of the Vinnytsia region. During the experiment, the efficiency of bees' use of the honey collection in the zone of their productive flight was determined. The condition of bee colonies, their development, and productivity were also determined.

Research methods used in the research: zootechnical - assessment of bee colonies, their productivity, determination of honey supply of fodder resources, the phenological - flowering time of plants, ethological - flightharvesting of bees, and statistical - biometric processing of research materials (Brovarskyi et al 2017).

Three bee colonies of medium strength were used to assess the honey harvest conditions of fruit trees, white acacia, and sunflower. The count was performed every hour.

Honey-producing conditions and nectar-bearing properties of plants were evaluated according to the size of the bribe - the amount of nectar that enters the hive in one day or for a certain period of flowering of certain honey plants.

The flight activity of bees was studied by the number of individuals arriving in the hive in an average of 3 minutes.

The number of broods in the families was determined using a frame grid with squares of $5 \times 5 \mathrm{~cm}$, each containing 100 cells.

Biometric processing of research data was carried out according to the method of N.A. Plokhinsky using MS Excel software using built-in statistical functions.

\section{Results and Discussion}

In the conditions of the Vinnytsia region, the change of overwintering bees by the young generation ends in the first period, and the strength of families still does not change. The second period is a period of intensive growth, which lasts in strong families until mid-June, in weak ones much longer until early July. The third period - the accumulation of young bees before the honey harvest lasts all of July. Strong families can begin the productive use of the honey collection, and the weak use part of the main bribe for their development. At the end of July, there is a maximum number of bees in the families. 
The fourth period is the period of preparation for winter (August-September). During this period, the bulk of the bees of the older generation retreats and continues to reduce the strength of the bee colonies gradually. Families that had more bees at the beginning of the season retain this advantage in the fall.

The daily flight activity of bees depends on the type of plant and weather conditions. The largest bee pollen is collected during the flowering of early spring honeybees, fruit and berry crops, and weeds. This stability continues until the flowering of white acacia. Increased activity of bees in collecting pollen is associated with the cost of bee bread stocks because, during this period, the bees are intensively growing brood. The number of flying bees and, accordingly, the frequency of bee visits by plants depends on the strength of the colonies (Adamchuk 2020). The largest amount of brood is grown by bees that consume fresh bee bread or pollen (Druzhbiak and Kyryliv 2010). The largest number of broods in bee colonies in late May-early June and, accordingly, during this period, bees bring the most pollen to the nest - $271.38 \mathrm{~g}$ (Figure 1).

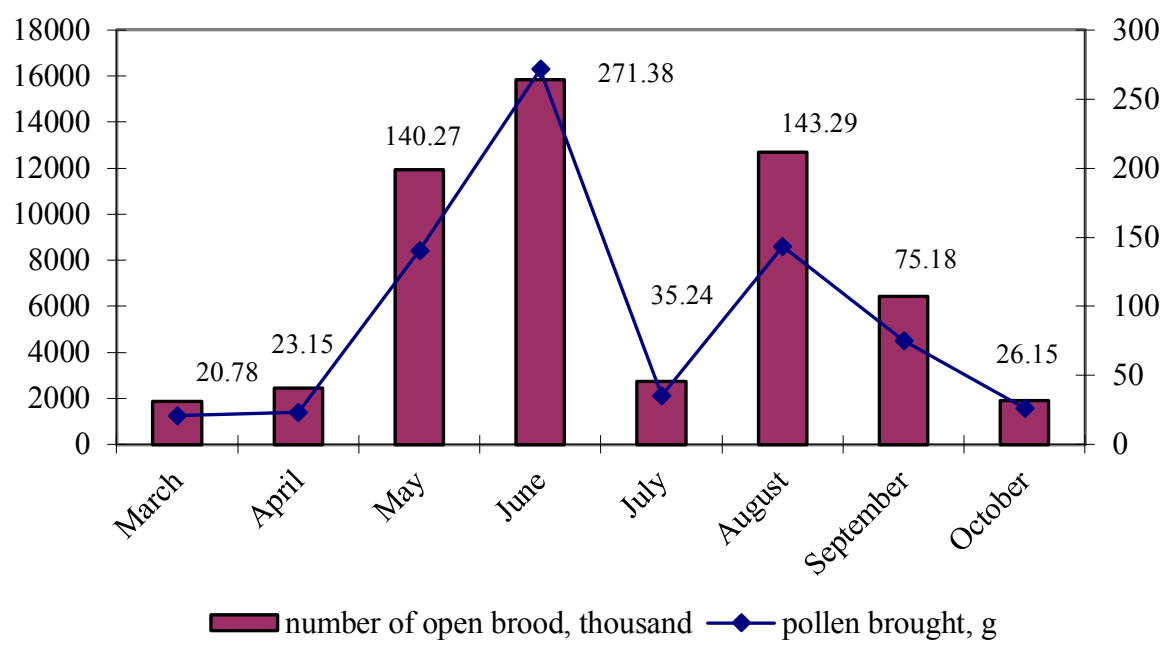

Figure 1 Dependence of pollen collection on the amount of brood in the beehive.

Bee colonies collect significantly more pollen in the spring than in the fall. After all, the need for protein feed to feed the brood forced the bees to work harder to collect pollen. During the spring period (March-May), bees brought $184.2 \mathrm{~g}$ of pollen to their nest. In the summer (449.91 g) compared to the spring period, more by $265.71 \mathrm{~g}(P<0.001)$, and the autumn $(101.33 \mathrm{~g})-$ less by $82.87 \mathrm{~g}(P<0.01)$.

The strength of the bee colony affects the percentage of pollen collection from different plant species. Mediumstrength bee colonies are especially active in collecting pollen, in which flight activity doubles (Mishchenko 2015). Due to the high need for protein feed, strong families collect it from all plant species within a productive range and medium and weak families from plants growing near the apiary.

Bee colonies show high pollen collection activity in the spring when the bees build up before honey collection. The pollen collection by bees weakens in the post-spring period of the active season, during which the necessary stock is created in the nest. Instead, much of the bees switched to collecting nectar. If the percentage of bees engaged in pollen collection in the spring is $38.7 \%$ of the total number of arrivals in the hive, then during the summer honey harvest, this figure decreased by $20.3 \%(P<0.001)$, Before the main honey harvest, the pollen activity of bees decreased even more. Compared to the previous period of summer honey harvest, the number of individuals decreased by $4.2 \%(P<0.01)$, with the spring period - by $24.5 \%(P<0.001)$ (Table 1$)$.

During daylight, there was a high intensity of pollen collection during the flowering of fruit trees. The largest bees that arrived with a brood were found from 10 to 18 hours from 52 to 31 arrivals in 3 minutes (Figure 2).

Table 1 Pollen collection of bees in different periods of honey collection.

\begin{tabular}{lcc}
\hline Honey collection period & \multicolumn{2}{c}{ Number of bees arrived in 3 minutes } \\
\cline { 2 - 3 } & total, pcs & $\%$ of bees with pollination \\
\hline Early spring period & $127 \pm 2$ & 38.7 \\
\hline Summer honey collection & $186 \pm 8$ & 18.4 \\
\hline Main collection of honey & $293 \pm 11$ & 14.2 \\
\hline
\end{tabular}




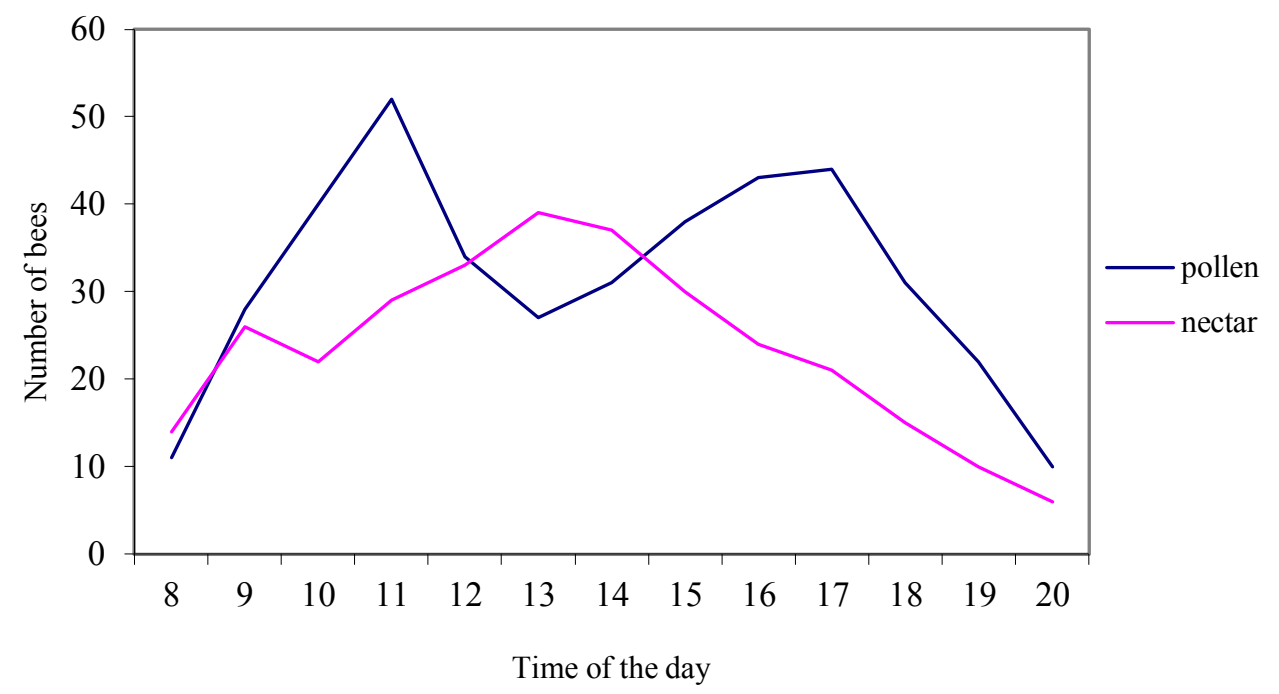

Figure 2 Daily dynamics of flight activity of bees during the flowering of fruit trees.

The peak of pollen collection occurs at 11:00 - 52 arrivals and 16:00-17:00 - 43-44 arrivals of bees with pollination. However, in the period from 13:00 to $14: 00$ hours, the activity of bees to collect nectar (39... 37) $(P<$ $0.001)$ is higher than the work of collecting pollen $(27 \ldots 31$ arrivals). The activity of bees in collecting nectar was much lower than that of pollen, which is because during this period, mainly honeysuckle blooms, which have low nectar productivity and high pollen productivity (Figure 2).

During the flowering of honeycombs with high nectar productivity, the work of bees to collect pollen is minimized. During the flowering of white acacia and sunflower, bees begin to intensify their work on collecting nectar long before dawn.

In the honey harvest from white acacia, the flight activity of bees to collect pollen is significantly reduced. The redistribution of functions in the procurement of protein and carbohydrate feeds contributed to increased nectar collection. The collection of pollen from white acacia is almost uniform (Figure 3).
In the evening (16:00-21:00), the number of arriving bees with a new one was much less than in the middle of the day. The peak in the collection of bee pollen occurs at 9:00 to 13:00 - 33-55 bees, and from 14:00 to 20:00, the activity is almost at the same level $-26-35$ arrivals. The flight activity of bees to collect nectar in the morning to 14:00-15:00 hours is gradually increasing - from 11 to 86 arrivals in 3 minutes. From $16: 00$ to evening, collecting nectar activity decreases to 31... 12 arrivals in 20:00-21:00.

Bees visit sunflowers most actively in the morning (from 10:00 to 16:00), although nectar flowers secrete nectar throughout the day (Figure 4).

The dynamics of flight activity of bees on sunflower is radically different from previous periods. Pollen collection activity is uneven - from 6:00 to 9:00, it increases, then decreases to $12: 00$, and from 12:00 to $18: 00$, bees do not collect pollen. Instead, they intensify their work on collecting nectar. Flight pollen collection activities are resumed in the evening from $6 \mathrm{pm}$ to $9 \mathrm{pm}$. Bees collected nectar from sunflowers from 9:00 to 19:00.

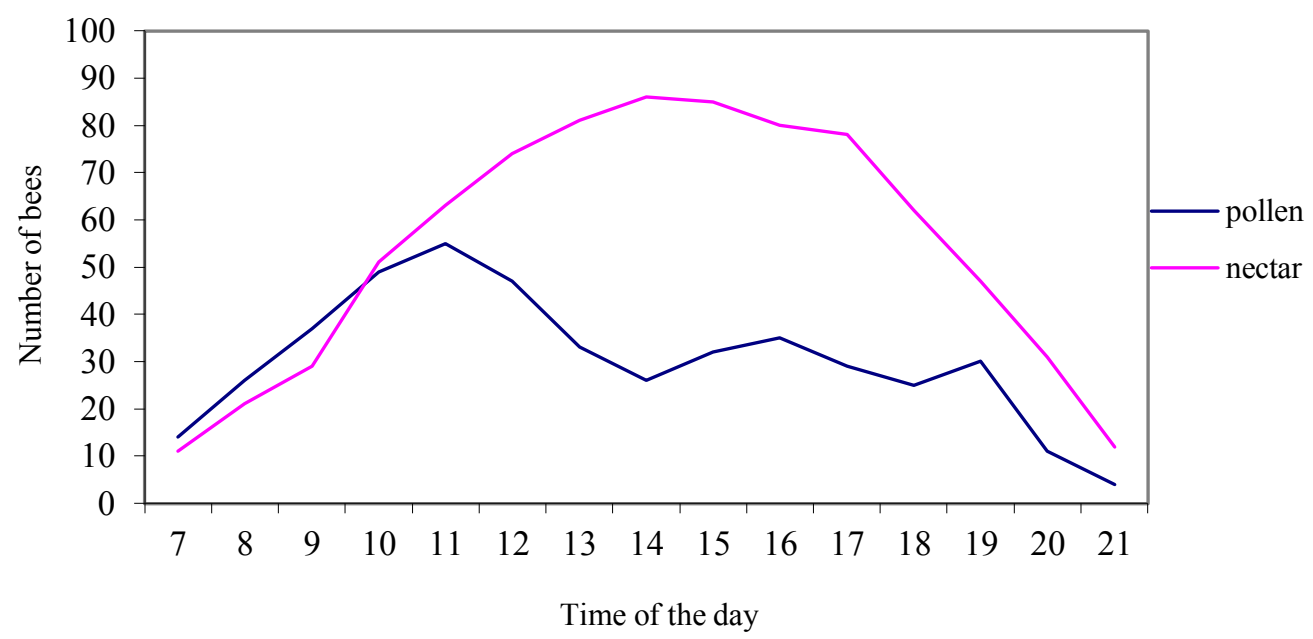

Figure 3 Daily dynamics of flight activity of bees during the flowering of white acacia. 


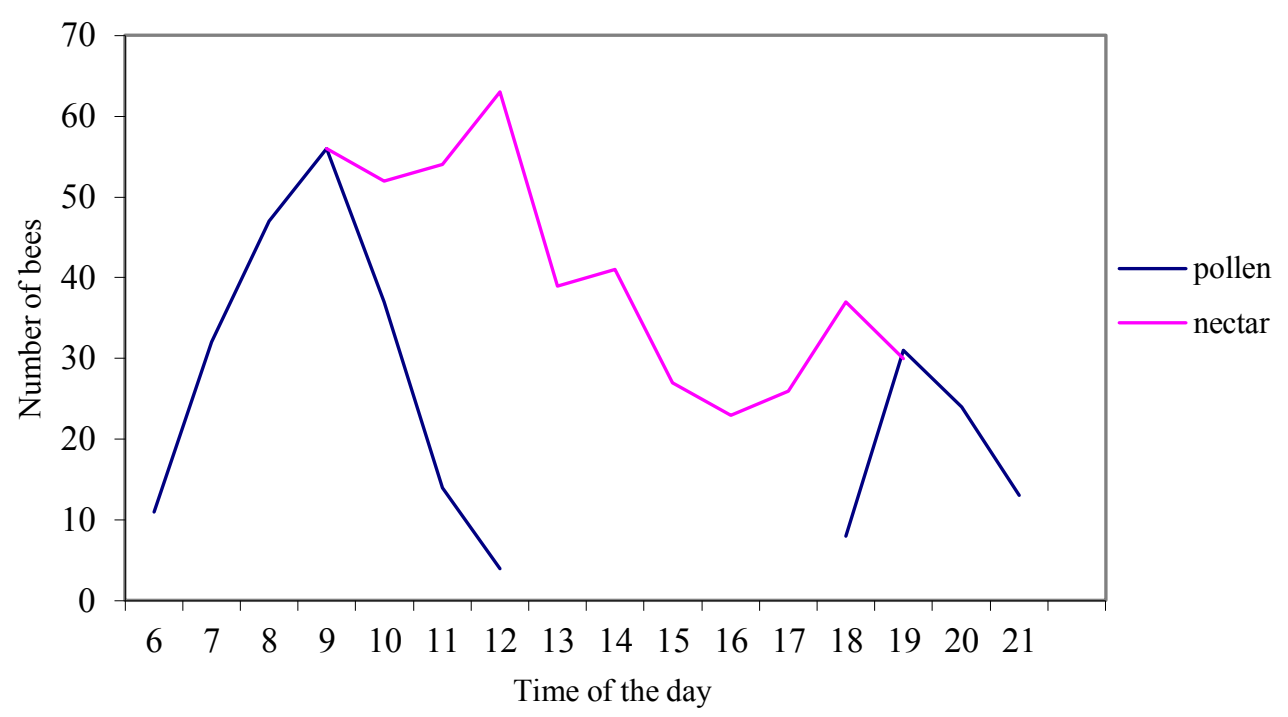

Figure 4 Daily dynamics of flight activity of bees during sunflower flowering.

\section{Conclusions}

During the summer, the bees brought $265.71 \mathrm{~g}$ more during the autumn $-82.87 \mathrm{~g}$ less pollination than the spring period. During the summer honey harvest, the percentage of bees engaged in pollen collection decreased by $20.3 \%$, to the main honey harvest by $24.5 \%$. During the flowering of honeycombs with high nectar productivity, the work of bees to collect pollen is minimized. The peak for collecting bee pollen from fruit trees is 10-11, white acacia - 9-13, sunflower - 6-9 hours. In the honey harvest from white acacia, the flight activity of bees to collect pollen decreases, nectar - increases. On sunflower, bees from 12:00 to 18:00 do not collect pollen, only nectar.

\section{Conflict of Interest}

The authors declare that they have no conflict of interest.

\section{Funding}

This research did not receive any financial support.

\section{References}

Abrol DP (2006) Foraging behaviour of bees as influenced by quality and quantity of rewards from flowers. Journal of Asia-Pacific Entomology 9:145148.

Adamchuk LO (2020) Efektyvne vykorystannia bdzhil dlia zapylennia sadiv ta yahidnykiv : metodychni rekomendatsii, Kyiv.

Brovarskyi VD, Brindza Ya, Otchenashko VV, Povoznikov MH, Adamchuk LO (2017) Metodyka doslidnoi spravy u bdzhilnytstvi Navchalnyi posibnyk, Kyiv. Druzhbiak Al, Kyryliv Yal (2010) Sezonni osoblyvosti bilkovoho kharchuvannia medonosnykh bdzhil. Naukovyi visnyk LNUVMtaBT imeni S. Z. Gzhytskoho 12:43-47.

Cherhyk MI, Kharchenko PA, Bodnarchuk LI (1972) Vykorystannia bdzhil na zapylenni silskohospodarskykh roslyn, Kyiv.

Haeva DV (2015) Opыlenye kak эkosystemnaia usluha v ahrarnom pryrodopolzovanyy. Vestnyk Baltyiskoho federalnoho unyversyteta ym. Y. Kanta. Seryia: Estestvennbe y medytsynskye nauky 1:19-34.
Hung KL, Kingston JM, Albrecht M, Holway DA, Kohn JR (2018) The worldwide importance of honey bees as pollinators in natural habitats. Proceedings of the Royal Society B: Biological Sciences 285:2017-2140.

Kryvtsov NY, Lebedev VY (2019) Pchelovodstvo: razvedenye y soderzhanye pchelynukh semei: uchebnyk y praktykum dlia akademycheskoho bakalavryata, Moskva.

Kryvtsov NY, Lebedev VY, Chupakhyna OK, Chupakhyn VY (2017) Osnovnыe medonosы y pcheloopыlenye.

Losiev OM, Holovetskyi II (2013) Sanitarno-hihiienichni aspekty vedennia bdzhilnytstva, Kyiv.

Mishchenko O. A. (2015) Vplyv vidboru bdzholynoho obnizhzhia na rozvytok i lotnu diialnist bdzholynykh simei. Naukovyi visnyk Natsionalnoho universytetu bioresursiv i pryrodokorystuvannia Ukrainy 223:143-149.

Moquet L, Bruyère L, Pirard B \& Jacquemart AL (2017) Nectar foragers contribute to the pollination of buzz-pollinated plant species. American Journal of Botany 104:1451-1463.

Mudrak OV, Yelisavenko YuA, Polishchuk VM, Mudrak GV (2019) Assessment of forest ecosystems of Eastern Podillya natural reserve fund in the regional econet structure. Ukrainian Journal of Ecology 9:187-192.

Mudrak OV, Mudrak HV, Razanov SF, Kavun ZhA (2018) Ecologicalcohenological analysis of Eastern Podillya flora. Ukrainian Journal of Ecology 8:204-209.

Pantsyreva HV, Myalkovsky RO, Yasinetska IA, Prokopchuk VM (2020) Productivity and economical appraisal of growing raspberry according to substrate for mulching under the conditions of podilia area in Ukraine. Ukrainian Journal of Ecology 10:210-214.

Razanova OP (2018) Increasing meat quality quails fed by biological active additives based on submerged bees. Ukrainian journal of ecology 8:631-636. Skoromna OI, Razanova OP (2019) Rozvytok haluzi bdzhilnytstva yak dzherelo struktury prodovolchoi bezpeky. Ahrarna nauka ta kharchovi tekhnolohii 3:70-82.

Stroikov SA (1988) Zahotovka perhy y pultsы dlia pchel. Nauchnoyssledovatelskyi ynstytut pchelovodstva, Rubnoe.

Moskalets TZ, Vovkohon AH, Barat YM, Knyazyuk OV, Verheles PN (2020) Morphological and ecological peculiarities of checker tree mountain ash (Torminalis glaberrima) plants and biochemical composition of its fruits. Regulatory Mechanisms in Biosystems 11:48-56. 